\title{
PELAKSANAAN TUGAS DAN FUNGSI KOMITE SEKOLAH
}

\author{
Yuliana.F. Lilistian, SE, M.Si \\ Fakultas Ilmu Sosial dan Ilmu Politik Universitas Kapuas \\ Email:Yulianaunka@gmail.com
}

\begin{abstract}
Abstrak : Peningkatan mutu pendidikan merupakan sasaran pembangunan dibidang pendidikan nasional dan merupakan bagian integral dari upaya peningkatan kualitas manusia Indonesia secara menyeluruh. Upaya mencerdaskan kehidupan bangsa menjadi tanggung jawab bersama yaitu pemerintah, sekolah dan orang tua. Sejak pemerintah memberlakukan desentralisasi pendidikan, peran masyarakat menjadi sangat penting dalam mendukung keberhasilan pelaksanaan proses belajar mengajar di sekolah. Untuk mengembangkan aspirasi masyarakat tersebut maka dibentuklah suatu wadah yang dinamakan Komite Sekolah. Berdasarkan Undang-Undang Nomor 32 Tahun 2004 Tentang Pemerintahan Daerah dan UndangUndang Nomor 35 Tahun 2004 Tentang Perimbangan Keuangan antara Pemerintah Pusat dan Daerah, yaitu membawa perubahan paradigma pengelolaan sistem pendidikan. Jika semula pendidikan ditangan pusat, maka sekarang pihak sekolah berhak untuk mengatur dirinya sendiri tanpa tergantung pada pemerintah yang direalisasikan dengan kemandirian sekolah dari aparat daerah dalam menentukan arah, kebijakan serta jalannya pendidikan masing-masing. Pelaksanaan tugas dan fungsi Komite Sekolah sudah ada pembagian tugas antar pengurus tetapi belum dijalankan secara maksimal. Ada dua aspek yang perlu diperhatikan dalam pembagian tugas yaitu, kemampuan menjalankan tugas dan sumber daya manusia. Adapun, delegasi wewenang sudah berjalan dengan baik antar pengurus Komite Sekolah. Cara delegasi wewenang tersebut adalah dari Ketua Komite kepada Wakil Ketua, Sekretaris Komite dan Bendahara Komite. Dan, dari Ketua Komite Sekolah kepada Seksi yang menangani setiap bidang. Mekanisme koordinasi dalam pelaksanaan tugas dan fungsi Komite Sekolah dilakukan melalui surat tugas. Metode yang diterapkan dalam pelaksanaan mekanisme koordinasi tugas pengurus Komite dengan perangkat Sekolah Dasar Negeri 01 adalah dengan pembagian tugas dan perintah dari Ketua Komite Sekolah dan Kepala Sekolah sebagai mitra kerja. Belum adanya penyusunan desain pekerjaan pada pengurus Komite Sekolah, oleh karen itu belum diketahui apakah desain pekerjaan tersebut dilakukan dengan penyederhaan tugas atau pemekaran pekerjaan. Pada faktor-faktor yang mempengaruhi diperoleh hasil bahwa pada manajemen sumber daya manusia sistem penempatan pengurus Komite Sekolah berdasarkan dari tingkat pendidikan dan pengalaman selama menjadi pengurus Komite Sekolah sebelumnya. Pada motivasi, memperlihatkan bahwa belum adanya motivasi Komite Sekolah dalam pelaksanaan tugas dan fungsinya. Pada pembagian tugas sudah dilakukan antar pengurus Komite Sekolah, tetapi masih belum dilaksakan dengan baik sesuai dengan tugas dan fungsi dari masing-masing pengurus. Delegasi wewenang sudah ada, dan mekanisme koordinasi masih belum dijalankan dengan baik. Untuk desain pekerjaan, karena pembagian tugas sudah ada, tetapi desain pekerjaan yang dijalankan belum terlaksana dengan baik. Pada manajemen sumber daya manusianya masih perlu diadakan pembinaan kepada pengurusnya sementara tingkat motivasi yang ada masih kurang dimiliki oleh pengurus Komite Sekolah.. Tugas dan fungsi dapat berjalan dengan baik maka memang perlu adanya pertemuan untuk merumuskan panduan mengenai sistem dan cara kerja dari Komite Sekolah.
\end{abstract}

Kata Kunci : Pelaksanaan, Tugas, Fungsi, Komite Sekolah

Dalam otonomi pendidikan masyarakat perlu dilibatkan dalam kegiatan sekolah yang tujuannya untuk menciptakan rasa tanggung jawab sehingga timbul rasa memiliki terhadap sekolah. Bentuk dari keterlibatan masyarakat terhadap sekolah yaitu dengan adanya Komite Sekolah yang berperan sebagai pertimbangan (advisory), pendukung (supporting), pengontrol (controlling), dan penghubung (medioator). Dalam hal ini pelaksanaan program sekolah juga melibatkan unsur Komite Sekolah sebagai penangungjawabnya, yang diperlukan manajemen untuk mencapai tujuan yang diinginkan. Komite sekolah dibentuk disetiap sekolah sebagai hasil dari SK Menteri Nomor 202 Tahun 2003 untuk desentralisasi. Komite diharapkan bekerjasama dengan kepala sekolah sebagai partner untuk mengembangkan kualitas sekolah dengan menggunakan konsep manajemen berbasis sekolah dan masyarakat yang demokratis, transparan dan akuntabel. Berdasarkan Undang-undang Pendidikan (2003:56) memberikan kepada Komite Sekolah dan Madrasah peran untuk meningkatkan kualitas pelayanan pendidikan melalui : (i) nasihat; (ii) pengarahan; (iii) bantuan personalia, material dan fasilitas; (iv) pengawasan pendidikan. 
Manajemen merupakan suatu rangkaian proses bagaimana tujuan yang telah direncanakan dapat tercapai, dimana rangkaian proses itu haruslah dilaksanakan dengan baik dan terarah didalam suatu kendali manajemen dan kinerja, karena dengan demikian resiko kegagalan akan dapat diminimalisir atau dengan kata lain dapat mengurangi hambatan dan resiko yang muncul. Dengan melakukan serangkaian proses dalam pencapaian tujuan dengan baik dan benar setidaknya dapat melakukan suatu tindakan yang menuju kearah yang diinginkan sehingga kinerja dapat dilakukan dengan optimal.

Komite sekolah sebagai mediator dengan masyarakat yang melibatkan orang tua siswa dalam kegiatan sekolah dalam hal ini melalui pembentukan paguyuban kelas. Pertemuan-pertemuan formal dilakukan secara regular, tetapi tidak sering. Sering mereka diundang oleh Kepala Sekolah untuk mendiskusikan perencanaan, pelaksanaan dan pendanaan rencana pengembangan sekolah (RAPBS). Program-program yang dikembangkan dalam pertemuan-pertemuan ini menunjukkan kecenderungan terfokus pada perbaikan fisik sekolah. Aktivitas peningkatan kualitas pendidikan pada umumnya nampak tidak mengacu pada isuisu penting belajar mengajar. Walaupun demikian, dampak positif perencanaan bersama pengembangan program dapat dilihat di banyak sekolah. Komite sekolah dengan semangat tinggi merinci perubahan-perubahan disekolah di dalam 4 bidang peningkatan pembelajaran, guru dan kesejahteraanya, fasilitas sekolah yang lebih baik, dan perbaikan lingkungan fisik. Dalam melaksanakan perannya, Komite Sekolah di Sekolah Dasar Negeri 01 Desa Nanga Dangkan memiliki tugas pokok dan fungsi masing-masing sesuai dengan klasifikasi jabatannya. Namun, berdasarkan pengamatan awal penulis, bahwa kecenderungan Komite Sekolah masih lamban dalam menangani tugas khususnya dalam pengawasan pelaksanaan program sekolah, bahkan seringkali pihak komite sekolah juga jarang menghadiri rapat-rapat yang diadakan oleh pihak sekolah. Hal ini menunjukkan indikasi asumsi penulis bahwa masih lemahnya tanggung jawab yang ada pada Komite Sekolah yang nantinya akan berakibat pada hasil pelaksanaan tugas. Lemahnya tanggung jawab ini, ada kecenderungan menjadi suatu kebiasaan sehingga masyarakat beranggapan bahwa peranan Komite Sekolah tidak cukup mempengaruhi kebijakan yang dikeluarkan oleh Pihak Sekolah.

Dewan Pendidikan dan Komite Sekolah dibentuk berdasarkan Undang-Undang Nomor 25 Tahun 2000 tentang Program Pembangunan Nasional (PROPENAS). Dewan pendidikan dibentuk disetiap Kabupaten/Kota, sementara Komite Sekolah dibentuk di setiap satuan pendidikan atau sekelompok satuan pendidikan. Maksud dibentuknya Komite Sekolah adalah agar ada suatu organisasi masyarakat sekolah yang mempunyai komitmen dan loyalitas serta peduli terhadap peningkatan kualitas sekolah. Komite sekolah yang dibentuk dapat dikembangkan secara khas dan berakar dari budaya, demografis, ekologis, nilai kesepakatan serta kepercayaan yang dibangun sesuai dengan potensi masyarakat setempat. Oleh karena itu, Komite Sekolah yang dibangun harus merupakan pengembang kekayaan filosofis masyarakat secara kolektif. Artinya, Komite Sekolah mengembangkan konsep yang berorientasi kepada pengguna, berbagi kewenangan dan kemitraan yang difokuskan pada peranan komite sekolah khususnya pada pelaksanaan tugas dan fungsi.

Keberadaan Komite Sekolah harus bertumpu pada landasan partisipasi masyarakat dalam meningkatkan kualitas pelayanan dan hasil pendidikan disatuan pendidikan/sekolah. Oleh karena itu, pembentukan komite sekolah harus memperhatikan pembagian peran sesuai dengan posisi dan otonomi yang ada. Kesatuan sosial dalam hal Komite Sekolah adalah masyarakat sekolah yang peduli pendidikan yang berinteraksi satu sama lain. Pengertian dikoordinasikan secara sadar bahwa organisasi komite sekolah dijalankan berdasarkan prinsip-prinsip manajemen. Keterikatan yang terus menerus berarti masyarakat secara sadar merasa terikat dengan sekolah karena mereka peduli dengan pendidikan. Komite sekolah dapat memutarkan roda organisasi dengan dimulai dengan hal-hal yang sederhana. Hal yang paling sederhana yang dapat dilakukan Komite Sekolah adalah konsolidasi organisasi. Sebagian besar komite mempunyai pengurus 3 ( tiga ) orang, dan meniru struktur organisasi seperti disarankan. Kepala sekolah dengan jelas diharapkan menjadi penghubung bagi komite, tidak dapat menjadi anggota komite.

Setiap sekolah diwakili oleh paling sedikit satu orang guru dalam komite, meskipun demikian $43 \%$ bendaharawan adalah wanita. Beberapa komite, ada yang tidak mempunyai anggota wanita. Pengetahuan mengenai pendidikan, yang nampak dari tugas sehari-hari didalam bidang pendidikan dan pengalaman sebagai anggota BP3 kelihatannya tidak menjadi faktor utama untuk menjadi pengurus. Kelihatannya pengurus dipilih karena keterampilan mereka dan jaringan hubungan yang mereka miliki. Sebagian besar anggota komite mempunyai minat menjadi anggota komite di sekolah anaknya. Anggota komite sekolah pada umumnya diplih melalui musyawarah tidak melalui pemilihan. Beberapa anggota BP3 diangkat kembali menjadi anggota komite dan tugasnya diperluas. Banyak komite yang sudah mempunyai Surat Keputusan 
dari kepala sekolah sedangkan komite yang baru dibentuk (tahun 2003) Surat Keputusannya masih sedang diproses.

Komite sekolah sebagai mediator dengan masyarakat yang melibatkan orang tua siswa dalam kegiatan sekolah melalui pembentukan paguyuban kelas. Pertemuan-pertemuan formal dilakukan secara regular, tetapi tidak sering. Sering mereka diundang oleh Kepala Sekolah untuk mendiskusikan perencanaan, pelaksanaan dan pendanaan rencana pengembangan sekolah (RAPBS). Dalam perencanaan, pelaksanaan dan pendanaan rencana pengembangan sekolah (RAPBS), setiap anggota Komite Sekolah dapat diundang oleh Kepala Sekolah maupun oleh Ketua Komite untuk membicarakan dan mendiskusikan hal-hal yang berkaitan dengan kalender sekolah. Programprogram yang dikembangkan dalam pertemuanpertemuan ini menunjukkan kecenderungan terfokus pada perbaikan fisik sekolah. Aktivitas peningkatan kualitas pendidikan pada umumnya nampak tidak mengacu pada isu-isu penting belajar mengajar.

Walaupun demikian, dampak positif perencanaan bersama pengembangan program dapat dilihat di banyak sekolah. Komite sekolah dengan semangat tinggi merinci perubahanperubahan disekolah di dalam 4 ( empat ) bidang peningkatan pembelajaran, guru dan kesejahteraanya, fasilitas sekolah yang lebih baik, dan perbaikan lingkungan fisik. Kendala-kendala yang paling menonjol adalah usaha sekolah untuk mendanai program yang menjadi unggulan dan bisa dilaksanakan, oleh karena itu perencanaan dilakukan lebih dahulu, dan kemudian dicarikan pendanaannya. Komite dan sekolah melaksanakan kerjasama dalam hal ini dengan menggunakan berbagai cara untuk mengumpulkan dana bagi sekolah. Guna menjalankan roda organisasi komite sekolah perlu adanya pembagian tugas yang jelas bagi setiap personel pada setiap jabatan yang diembannya, sehingga tidak terjadi tumpang tindih pelaksanaan tugas. Dalam hal ini pembagian tugas. Dalam hal ini pembagian tugas berupa panduan siapa mengerjakan apa dan masing-masing personel bertanggung jawab atas terlaksanannya tugas yang diemban. Struktur organisasi berkaitan dengan hubungan yang relatif tetap diantara berbagai tugas yang ada dalam organisasi. Pembentukan struktur organisasi menghadapi dua hal pokok, pertama deferensiasi atau pembagian tugas diantara para anggota organisasi, dan kedua, integrasi atau koordinasi atas apa yang telah dilakukan dalam pembagian tugas tersebut. Oleh karenanya, bidang struktur organisasi membahas cara bagaimana organisasi membagi tugas diantara anggota organisasi dan menghasilkan koordinasi diantara tugas-tugas tersebut.
Pembagian tugas berkaitan dengan proses pembagian tugas kedalam suatu unit-unit tugas yang secara berturut-turut lebih kecil. Semua tugas dispesialisasikan kedalam derajat yang sama, karena tidak semua orang dapat melakukan tugasnya secara bersama karena beberapa tugas sangat berbeda dengan tugas lainnya. Salah satu manfaat dalam mengorganisasikan tugas adalah bahwa kelompok orang yang bekerja sama melalui pembagian kerja mampu menghasilkan lebih dari yang mereka hasilkan sendiri. Perencanaan tenaga kerja yang belakangan ini berhubungan dengan sistem-sistem tenaga kerja yang bersifat kualitas dan kuantitas. Sistem tenaga kerja terdiri atas 4 ( empat ) unsur, yaitu : Struktur-struktur jabatan; Jalur-jalur karier; Kebijakan-kebijakan untuk memperbaiki stabilitas pekerjaan; dan Kebijakankebijakan pengurangan tenaga kerja dengan jalan penggeseran, pemberhentian biasa dan pemecahannya.

Isu utama dari pembagian kerja adalah sejauh mana tugas-tugas seharusnya dispesialisasikan. Spesialisasi akan rendah jika pegawai melakukan beraneka ragam pekerjaan, dan sebaliknya spesialiasasi akan tinggi jika pegawai hanya melakukan suatu tugas. Selain itu, spesialisasi tugas yang tinggi dapat juga menimbulkan rasa bosan. Akan tetapi ada keuntungan tertentu dari spesialiasi tugas yang tinggi, keuntungan utamanya adalah produktivitas yang tinggi. Ada beberapa alasan mengapa spesialiasasi dapat meningkatkan produktifitas yaitu : (1) dapat meningkatkan keahlian karena melakukan aktivitas berulang-ulang, (2) mengurangi kebutuhan akan pelatihan untuk mematangkan tugasnya, (3) mengurangi waktu terbuang dari tugas yang satu ke tugas lainnya, (4) dapat dikembangkan alat otomatis khusus untuk menyelesaikan suatu tugas serta (5) pengendalian kualitas dapat lebih baik.

Untuk pembagian tugas merupakan sumber informasi yang penting untuk semua perencanaan tenaga kerja. Dalam kenyataan, uraian-uraian demikian adalah juga penting untuk seleksi, latihan, beban kerja, insentif-insentif dan administrasi gaji. Semua bidang kepegawaian ini menuntut bahwa kewajiban-kewajiban, tugas-tugas, dan syarat-syarat pegawai yang penting dibuat dengan jelas untuk setiap jabatan dalam organisasi. Jelas ada beberapa cara untuk mengelompokkan dan menyusun kewajiban-kewajiban dan tugastugas dan hal ini agaknya akan berlainan,tergantung kepada apakah kita berhubungan dengan pekerjaanpekerjaan tangan, pekerjaaan tata usaha, ataukah pekerjaan-pekerjaan berkeahlian (professional). Menurut Gitosudarmo dan Sudita (2000:270) "delegasi wewenang berkaitan dengan lokasi kewenangan dalam proses pengambilan keputusan atau sejauh mana wewenang pengambilan keputusan tersebar dalam hirarki organisasi". 
Kewenangan pengambilan keputusan yang tersebar secara luas dan hirarki organisasi disebut dengan desentralisasi. Sedangkan apabila kewenangan dalam proses pengambilan keputusan hanya berada pada tingkat atas dalam organisasi disebut sentralisasi. Telah disinggung dimuka bahwa tujuan akhir dari keberadaan Komite Sekolah di setiap satuan pendidikan atau kelompok satuan pendidikan adalah untuk meningkatkan mutu pendidikan di satuan pendidikan tersebut. Ada prinsip yang harus dipegang oleh semua anggota Komite Sekolah yaitu Komite Sekolah tidak mengambil peran satuan pendidikan, tidak juga mengambil peran pemerintah atau birokrat. Sentralisasi lebih tepat diterapkan pada organisasi yang masih kecil dimana jumlah pekerja relative sedikit dan tugas-tugas tidak begitu kompleks, sedangkan desentralisasi lebih tepat diterapkan pada organisasi yang relatif besar dimana perlu adanya kewenangan dan partisipasi dari berbagai hirarki dalam organisasi untuk memutuskan sesuatu yang berkaitan dengan tugasnya, sehingga keputusan yang diambil lebih cepat. Meningkatnya desentralisasi menyebabkan organisasi semakin efektif karena desentralisasi memberikan otonomi dan tanggung jawab yang lebih besar sampai pada hirarki organisasi yang paling bawah, sehingga organisasi lebih efektif mengorganisir sumber daya manusianya. Desentralisasi juga dapat menimbulkan kepuasan kerja dan komitmen yang lebih tinggi dalam pelaksanaan suatu keputusan. Salah satu peran komite sekolah adalah sebagai mediator antara sekolah dan masyarakat yang dianggap sebagai criteria kefektifan komite. Bahkan, pengumpulan dana suatu kegiatan yang memerlukan pemikiran dan tenaga dari komite, tidak dianggap sebagai tanda keefektifan komite. komite sekolah yang ideal di masa depan mempunyai peran yang lebih besar daripada perannya sekarang. Banyak yang menganggap bahwa lingkungan kerja yang bagus dan anggota yang berkualitas sangat penting, sehingga komite dapat bekerja secara efektif bersama-sama dengan sekolah dan masyarakat untuk meningkatkan mutu belajar mengajar.

Organisasi perlu mengkoordinasikan berbagai aktivitas dari para anggotanya. Pekerja pada tingkat bawah dalam melaksanakan tugasnya harus sejalan dengan tujuan organisasi secara keseluruhan, dan manajer pada tingkat atas dalam organisasi perlu mengetahui pelaksanaan aktivitas dari orang-orang pada tingkat bawah dalam organisasi. Organisasi menggunakan beraneka ragam mekanisme integrasi untuk menghasilkan koordinasi. Gitosudarmo dan Sudita (2000:273) menyatakan tiga metode untuk melakukan koordinasi, yaitu: Standarisasi proses kerja. Tugastugas yang bersifat rutin dapat dikoordinasikan dengan prosedur standar operasi. Standarisasi hasil.
Ketika produk harus diproduksi sesuai dengan spesifikasi, maka spesifikasi tersebut dapat dipergunakan sebagai landasan untuk melakukan koordinasi aktivitas. Standarisasi keahlian. Tingkat keahlian yang tinggi melalui pelatihan yang dilakukan terhadap karyawan dapat mengkoordinasikan aktivitasnya melalui pelaksanaan dari teknik pelatihan yang telah diperolehnya.

Berkaitan dengan penentuan struktur organisasi hubungan tugas dan hubungan antarpribadi dari suatu pekerjaan dengan menentukan beberapa banyak kenakeragaman, tanggung jawab, signifikasi, dan otonomi pekerja diberikan oleh pekerjaannya. Salah satu unsur penting dalam struktur organisasi adalah desain pekerjaan. Menurut Gitosudarmo dan Sudita (2000:265) "desain pekerjaan berkaitan dengan struktur hubungan tugas dan hubungan antar pribadi dari suatu pekerjaan dengan menentukan berapa banyak keanekaragaman tanggungjawab, signifikansi, dan otonomi pekerjaan yang diberikan oleh pekerjaannya". Desain pekerjaan yang dirancang dengan baik akan dapat meningkatkan motivasi yang merupakan factor penentu produktivitas seseorang maupun organisasi. Desain pekerjaan berpengaruh besar terhadap efektifitas organisasi. Pekerjaan yang dirancang dengan baik akan dapat meningkatkan motivasi yang merupakan salah satu faktor yang menentukan prestasi kerja seseorang atau organisasi. Kepuasan kerja dipengaruhi oleh tuntutan pekerjaaan dan oleh sejauh mana tuntutan tugas tersebut sesuai dengan kemampuan seseorang.Kadangkala perubahan tugas yang sangat simpel dapat menyebabkan perubahan besar pada pemegang tugas tersebut. Dengan berkembangnya organisasi dan perubahan faktor lingkungan menyebabkan organisasi perlu melakukan desain ulang terhadap pekerjaan.

Gitosudarmo dan Sudita (2000:280) menyatakan "ada dua (2) strategi utama dalam mendesain ulang pekerjaan adalah spesialisasi tugas atau sering juga disebut penyederhanaan tugas ( $j o b$ simplification) dan pemekaran pekerjaan (job enlargement)". Dua strategi ini saling bertentangan. Penyederhanaan pekerjaaan adalah mengurangi jumlah elemen-elemen tugas yang dilakukan oleh pekerja, sedangkan pemekaran pekerjaan adalah membuat tugas-tugas yang lebih kompleks dengan meningkatkan jumlah tugas yang dilakukan masing-masing pekerja. Keberhasilan suatu organisasi dalam mencapai tujuannya salah satu indikator penentu adalah sumber daya manusia yang berkualitas. Untuk itu, diperlukan manajemen sumber daya manusia dalam pelaksanaannya. Hasibuan (1996:04) menyatakan bahwa manajemen berasal dari kata "to manage" yang berarti mengatur, mengurus atau mengelola. Banyak definisi yang telah diberikan oleh para ahli terhadap istilah manajemen ini. 
Namun dari sekian banyak definisi tersebut ada satu yang kiranya dapat dijadikan pegangan dalam memahami manajemen tersebut, yaitu : Manajemen adalah suatu proses yang terdiri dari rangkaian kegiatan, seperti perencanaan, pengorganisasian, penggerakandan pengendalian/ pengawasan, yang dilakukan untuk menetukan dan mencapai tujuan yang telah ditetapkan melalui pemanfaatan sumberdaya manusia dan sumberdaya lainnya. Menurut Sedarmayanti (2007:13) menyatakan bahwa manajemen sumber daya manusia adalah kebijakan dan praktek menentukan aspek "manusia" atau sumber daya manusia dalam posisi manajemen, termasuk merekrut, menyaring, melatih, memberi penghargaan dan penilaian. Tujuan manajemen sumber daya manusia secara umum adalah untuk memastikan bahwa organisasi mampu mencapai keberhasilan melalui orang. Secara khusus menurut Sedarmayanti (2007:16) menyatakan bahwa manajemen sumber daya manusia bertujuan untuk Memungkinkan organisasi mendapatkan dan mempertahankan karyawan cakap, dapat dipercaya dan memiliki motivasi tinggi, seperti yang diperlukan. Meningkatkan dan memperbaiki kapasitas yang melekat pada manusia kontribusi, kemampuan dan kecakapan mereka. Mengembangkan system kerja dengan kinerja tinggi yang meliputi prosedur perekrutan dan seleksi yang teliti; system kompensasi dan insentif yang tergantung kepada kinerja, pengembangan manajemen serta aktivitas pelatihan yang terkait 'hubungan bisnis'. Mengembangkan praktik manajemen dengan komitmen tinggi yang menyadari bahwa karyawan adalah pihak yang terkait dalam organisasi bernilai dan membantu mengembangkan iklim kerja sama dan kepercayaan bersama. Menciptakan iklim, dimana hubungan yang produktif dan harmonis dapat dipertahankan melalui asosiasi antara manajemen dengan karyawan. Mengembangkan lingkungan, dimana kerjasama tim dan fleksibilitas dapat berkembang. Membantu organisasi menyeimbangkan dan mengadaptasikan kebutuhan pihak terkait (pemilik, lembaga atau wakil pemerintah, manajemen, karyawan, pelanggan, pemasok dan masyarakat luas). Memastikan bahwa orang dinilai dan dihargai berdasarkan apa yang mereka lakukan dan mereka capai. Mengelola karyawan yang beragam, memperhitungkan perbedaan individu dan kelompok dalam kebutuhan penempatan, gaya kerja dan aspirasi. Memastikan bahwa kesamaan tersedia untuk semua. Mengadopsi pendekatan etis untuk mengelola karyawan yang didasarkan pada perhatian untuk karyawan, keadilan dan transportasi. Mempertahankan dan memperbaiki kesejahteraan fisik dan mental karyawan.
Sistem manajemen sumber daya manusia dapat menjadi sumber kapabilitas organisasi yang memungkinkan perusahaan atau organisasi dapat belajar dan mempergunakan kesempatan untuk peluang baru. Dalam proses prestasi kerja tentunya ada beberapa kondisi yang dapat mempengaruhinya. Dengan demikian, prestasi kerja yang efektif memerlukan adanya kondisi optimal, yaitu kondisi dimana para pegawai harus memiliki keahlian secara profesional di dalam setiap tugas yang diberikan dan bertanggung jawab sepenuhnya. Komite Sekolah merupakan asas utama dalam suatu organisasi yang menjadi perencana dan pelaku aktif dari setiap aktifitas organisasi, setiap orang akan berupaya menbangun, mendayagunakan semua sumber organisasinya secara optimal dalam rangka mencapai tujuannya. Secara konvensional, pembangunan sumber daya aparatur diartikan sebagai investasi human capital yang harus dilakukan sejalan dengan investasi physical capital. Menurut Siagian (1996:37) "alasan yang sangat fundamental kenapa hal tersebut perlu dilakukan karena dalam rangka menghadapi tuntutan tugas sekarang maupun mampu menjawab tuntutan masa depan, pengembangan dan partisipasi sumber daya aparatur merupakan keharusan mutlak". Sumber daya aparatur pada hakekatnya merupakan satu unsur yang menjadi sumber daya manusia dalam suatu organisasi. Sumber daya manusia inilah yang menyebabkan suatu organisasi bisa menjalankan kegiatannya sehari-hari. Kumorotomo (1994:39) mengatakan bahwa : "untuk mewujudkan profil sumber daya manusia yang berkarakater, paling tidak ada tiga hal mendasar yang perlu diusahakan dan diwujudkan : pola pikir,komitmen dan perilaku". Pola pikir dapat diartikan dengan melihat, mengartikan dan bereaksi terhadap satu fenomena tertentu. Pola pikir mempunyai arti yang sama dengan paradigma yang dipakai oleh seseorang, sekelompok orang atau masyarakat. Komitmen merupakan janji atau rasa tanggungjawab dalam menciptakan pembaharuan segala aspek kehidupan atau nilai-nilai hakiki dari perubahan. Sedangkan, perilaku merupakan serangkaian perbuatan atau pola-pola tindakan yang dijiwai atau disemangati oleh paradigma dan komitmen. Sebagai salah satu sumber daya organisasi yang sangat penting, maka sumber daya aparatur pemerintah perlu diperhatikan/dirancang sedemikian rupa agar dapat memenuhi harapan sebuah organisasi. Sehingga mempengaruhi administrasi dapat berjalan dengan baik, yakni sesuai dengan harapan maka perlu didukung oleh kualitas sumber daya aparatur yang memadai.

Pelaksanaan otonomi daerah didasarkan atas berbagai pertimbangan. Diantaranya adalah untuk memberikan keleluasaan kepada daerah untuk menetapkan organisasi sesuai dengan penilaian daerah masing-masing sehingga dapat 
membentuk organisasi yang efektif, efisien dan rasional sesuai kebutuhan daerah. Selain itu, organisasi daerah harus mampu berperan sebagai wadah bagi pelaksanaan fungsi-fungsi pemerintahan serta sebagai proses interaksi antara pemerintah dengan institusi daerah lainnya dan dengan masyarakat secara optimal. Menurut Hani (1986:146) "motivasi secara umum sering diartikan sebagai sesuatu yang ada pada diri seseorang yang dapat mendorong, mengaktifkan, menggerakkan dan mengarahkan perilaku seseorang". Dengan kata lain motivasi itu ada dalam diri seseorang dalam wujud niat, harapan, keinginan dan tujuan yang ingin dicapai. Motivasi juga merupakan salah satu komponen penting dalam meraih keberhasilan suatu proses kerja, karena memuat unsur pendorong bagi seseorang untuk melakukan pekerjaan sendiri maupun kelompok. Suatu dorongan dapat berasal dari dalam dirinya sendiri, yang berupa kesadaran diri untuk bekerja lebih baik atau memberikan yang terbaik bagi kelompok dengan berbagai macam alasan yang baik dan luhur. Namun, tidak semudah itu setiap orang mempunyai dorongan yang positif, mereka perlu dibantu oleh orang lain yang berperan sebagai pimpinan atau atasan. Dalam memberikan motivasi, atasan tidak sekedar mendorong sebisanya, akan tetapi mereka harus mempergunakan strategi agar apa yang dilakukan itu dapat menghasilkan yang lebih baik secara optimal. Beberapa faktor yang diperlukan untuk strategi antara lain, seperti tujuan, cara kerja, teknologi, masyarakat dan pelanggan, budaya SDM dan sumber daya lainnya. Dengan mengenal faktorfaktor tersebut akan dapat disusun suatu langkah bagaimana membuka peluang keberhasilan suatu organisasi.

Kemampuan, kecakapan, dan keterampilan pegawai tidak ada artinya bagi organisasi apabila pegawai tidak atau kurang berkemauan untuk melakukan pekerjaan yang telah di percayakan kepadanya. Oleh karena itu factor yang sangat menentukan adalah dorongan yang ada pada diri manusia yakni motivasi itu sendiri. Hal inilah yang menjadi tanggung jawab pimpinan untuk mengarahkan dan mendorong pegawai bawahannya untuk bekerja lebih baik sesuai dengan kemauan dan arahan pimpinan. Robbins (2000:198) mengemukakan bahwa motivasi adalah : "sebagai kesediaan untuk mengeluarkan tingkat upaya yang tinggi kearah tujuan-tujuan organisasi, yang dikondisikan oleh kemampuan upaya itu untuk memenuhi sesuatu kebutuhan individual". Upaya merupakan ukuran intensitas, dimana seseorang yang termotivasi akan mencoba kuat-kuat sehingga memungkinkan pencapaian tujuan organisasi secara maksimal. Sementara itu juga bagaimana motivasi itu dapat mempengaruhi prestasi kerja pegawai. Dapat diketahui dari teori motivasi sebagaimana diutarakan Husnan (1997:197) yaitu : "Content
Theory yang menjelaskan tentang apa dari motivasi, Process Theory yang menjelaskan bagaimana dari motivasi dan yang ketiga adalah Reinforcement Theory yang menekankan bagaimana perilaku dipercayai “.

Proses teori bukannya menekankan pada isi kebutuhan dan sifat dorongan dari kebutuhan tersebut, tetapi pendekatan ini menekankan pada bagaimana dengan tujuan apa setiap individu dimotivisir. Dalam hal kebutuhan hanyalah salah satu elemen dalam suatu proses tentang bagaimana individu bertingkah laku. Contoh : seseorang mungkin melihat adanya kemungkinan yang besar untuk menerima suatu imbalan seperti kenaikan gaji apabila mereka bekerja keras, sehingga imbalan ini disebut penunjang (incentive) atau motif untuk perilaku mereka. Dasar dari teori proses motivasi ini adalah adanya pengharapan (ecxpectacy) yaitu apa yang dipercayai oleh para individu akan mereka peroleh dari tingkah laku mereka. Sebagai contoh apabila karyawan dapat menyelesaikan pekerjannya tepat waktu maka mereka akan mendapat pujian dan sebaliknya jika mereka tidak mampu menyelesaikan pekerjaan tidak tepat waktu, mereka akan mendapat teguran.

Sementara itu, Maslow (dalam Sedarmayanti, 2007:234) juga mengemukakan konsep motivasi didasarkan pada hirarki kebutuhan, antara lain : Fisiologis : antara lain rasa lapar, haus, perlindungan (pakaian dan perumahan) dan kebutuhan ragawi lain. Keamanan : antara lain keselamatan dan perlindungan terhadap kerugian fisik dan emosional. Sosial : mencakup kasih sayang, rasa memiliki, diterima baik, dan persahabatan.

Penghargaan : mencakup faktor rasa hormat internal seperti : harga diri, otonomi dan prestasi. Eksternal seperti : status, pengakuan dan perhatian. Aktualisasi diri : dorongan untuk menjadi apa yang dia mampu menjadi. Mencakup, pertumbuhan, mencapai potensialnya, dan pemenuhan diri. Dari pendapat tersebut menunjukkan bahwa kebutuhan dasar menjadi prioritas seseorang, apabila kebutuhan dasar terpenuhi maka indivu akan melanjutkannya pada kebutuhan berikut dan demikian seterusnya. Dan dalam motivasi juga memerlukan teknik yang tepat dalam memotivasi. Sedarmayanti (2007:233) memberikan 2 (dua) teknik dalam memotivasi anggota, yaitu Motivasi langsung, yaitu penggerak kemauan pekerja yang secara langsung dan sengaja diarahkan kepada "internal motives" (motivasi dalam diri individu) pekerja dengan jalan memberikan perangsang (insentive). Motivasi tidak langsung, yaitu motivasi yang diberikan hanya merupakan fasilitas-fasilitas yang mendukung serta menunjang gairah kerja atau kelancaran tugas, sehingga para pegawai betah dan bersemangat melakukan pekerjaannya. Teknik 
motivasi langsung maupun tidak langsung bertujuan menggerakkan kemauan kerja dengan berbagai cara baik yang langsung pada individu dengan menyentuh persoalan kebutuhan individu (psikologis) atau juga melalui sarana atau fasilitas penunjang pelaksanaan tugas dilingkungan kerja khususnya.Berdasarkan uraian tersebut diatas mengungkapkan bahwa dengan hasil kerja yang dicapai oleh seorang karyawan dalam melakukan suatu pekerjaan dapat dievaluasi dari tingkat motivasi pegawainya, maka motivasi karyawan yang disebabkan oleh perilaku dapat menentukan dengan pencapaian target selama periode waktu yang dicapai organisasi.

\section{METODE}

Jenis Penelitian yang dilakukan adalah penelitian kualitatif tidak dimaksudkan untuk membuat generalisasi dari hasil penelitiannya. Subjek dan jenis data yang telah tercermin dalam fokus penelitian ditentukan secara sengaja. Jenis data yang digunakan dalam penelitian ini adalah jenis data primer dan data sekunder. Menurut Bagong \& Sutinah (2007: 91) menyatakan bahwa : "data primer adalah data yang dikumpulkan/ diperoleh langsung dari sumber yang bersangkutan sementara data sekunder adalah data yang telah dikumpulkan/diperoleh bukan dari sumber langsung melainkan sudah dari orang kedua atau organisasi yang lainnya ". Subjek penelitian merupakan orangorang yang berkompeten memberikan informasi yang diperlukan selama proses penelitian. Penulis menemui Kepala Sekolah, Ketua Komite Sekolah, Guru - guru Sekolah Dasar Negeri 01 Desa Nanga Dangkan 1 Kecamatan Silat Hulu serta Tokoh Masyarakat Desa Nanga Dangkan 1 Kecamatan Silat Hulu. Penelitian kualitatif merupakan proses penelitian yang berkesinambungan sehingga tahap pengumpulan data, pengolahan data dan analisis data di lakukan secara bersamaan selama proses penelitian. Dalam penelitian ini guna memperoleh data yang akurat dan berkualitas, maka menggunakan teknik pengumpulan data Wawancara, Observasi, serta Studi Dokumentasi. Setelah keseluruhan data yang diperlukan terkumpul melalui wawancara, observasi dan studi dokumenter, langkah selanjutnya adalah mengelompokkan data sesuai dengan jenis dan kelompok masing-masing data, kemudian di analisa oleh peneliti dengan mendeskripsikan data. Menurut Bagong dan Sutinah (2007:104) bahwa "analisis data adalah proses mengatur urutan data, mengorganisasikannya ke dalam suatu pola, kategori dan suatu uraian dasar". Adapun langkah-langkah analisis data dalam penelitian ini adalah Tahap persiapan, yaitu mengumpulkan data yang telah diolah, menyangkut peran pengawasan komite sekolah dalam pelaksanaan program sekolah yang mengambil studi kasus di Sekolah Dasar
Negeri 01 Desa Nanga Dangkan 1 Kecamatan Silat Hulu. dan faktor yang mempengaruhinya. 2 . Tahap penilaian data, dengan cara mengkategorikan data dengan sistem pencatatan dan pembandingan. Tahap interpretasi data, yaitu memberikan interpretasi/penafsiran terhadap data-data yang telah diseleksi untuk kemudian diuraikan atau dijabarkan dalam bentuk pernyataan ataupun argumentasi. Tahap kesimpulan, yaitu merupakan tahap akhir dari analisis data dimana peneliti memberikan keputusan akhir dari hasil penafsiran menyangkut peran pengawasan komite sekolah dalam pelaksanaan program sekolah yang mengambil studi kasus di Sekolah Dasar Negeri 01 Desa Nanga Dangkan I Kecamatan Silat Hulu. Penelitian ini dilakukan di Sekolah Dasar Negeri 01 Desa Nanga Dangkan 1 Kecamatan Silat Hulu. Pelaksanaan tugas dan fungsi Komite Sekolah yang merupakan ukuran dari pada produktivitas organisasi dan mengacu kepada peranan Komite Sekolah ,adanya kemudahan dalam pengumpulan data karena lokasi tersebut mudah dijangkau sehingga penulis dapat bekerja dengan baik dengan perhitungan dapat memanfaatkan waktu, biaya, tenaga dengan sebaik-baiknya. Komite Sekolah di Sekolah Dasar Negeri 01 Desa Nanga Dangkan 1 Kecamatan Silat Hulu merupakan salah satu unit organisasi di bidang pendidikan yang mempunyai peranan penting dalam melaksanakan sebagian kewenangan desentralisasi pendidikan khususnya dalam pengawasan pelaksanaan program sekolah.

\section{HASIL DAN PEMBAHASAN}

Dalam melaksanakan uraian tugas organisasi perlu adanya pembagian tugas. Adapun, pembagian tugas lebih banyak berhubungan dengan pekerjaan itu sendiri dari pada dengan orangnya yang melaksanakan pekerjaan. Titik berat uraian pekerjaan adalah menguraikan apa yang dilakukan, menguraikan kegiatan atau fungsi. Oleh karena itu uraian pekerjaan itu merupakan standar fungsi, uraian pekerjaan menunjukkan isi pekerjaan. Uraian pekerjaan merupakan suatu iktihisar data yang selektif. Pada organisasi Komite Sekolah sudah dilakukan pembagian tugas antar pengurus. Cara pembagian tugas tersebut adalah dengan berdasarkan uraian tugas pokok dan fungsi masingmasing anggota Komite. Selanjutnya, Ketua Komite Sekolah mengatakan bahwa ada dua aspek yang perlu diperhatikan dalam pembagian tugas yaitu, kemampuan menjalankan tugas dan sumber daya manusia. Pembagian tugas tersebut dapat meningkatkan pelaksanaan tugas dan fungsi Komite Sekolah. Dalam struktur pengurus organisasi tersebut, menampakkan adanya jabatan pengurus organisasi yang terdiri dari Ketua Komite, Sekretaris Komite, Bendahara Komite, dan Koordinator Bidang Komite. Adapun, dibawah Ketua ada tambahan jabatan untuk Wakil Ketua dan 
Sekretarisnya terbagi menjadi 2 yaitu Sekretaris I dan Sekretaris II. Tetapi, disini ada kekurangan karena tidak ada anggota dari pengurus Komite Sekolah tersebut.

Pembagian tugas berkaitan dengan proses pembagian tugas kedalam suatu unit-unit tugas yang secara berturut-turut lebih kecil. Semua tugas dispesialisasikan kedalam derajat yang sama, karena tidak semua pengurus Komite Sekolah dapat melakukan tugasnya secara bersama karena beberapa tugas sangat berbeda dengan tugas lainnya. Salah satu manfaat dalam mengorganisasikan tugas adalah bahwa pengurus Komite Sekolah dapat bekerja sama melalui pembagian tugas sehingga mampu menghasilkan lebih dari yang mereka hasilkan sendiri. Organisasi Komite Sekolah di Sekolah Dasar Negeri 01 Desa Nanga Dangkan 1 Kecamatan Silat Hulu sudah melakukan pembagian tugas antar pengurus. Cara pembagian tugas tersebut adalah dengan berdasarkan uraian tugas pokok dan fungsi masingmasing anggota Komite. Aspek yang perlu diperhatikan dalam pembagian tugas yaitu, kemampuan menjalankan tugas dan sumber daya manusia. Pembagian tugas tersebut dapat meningkatkan pelaksanaan tugas dan fungsi Komite Sekolah pada Sekolah Dasar Negeri 01 Desa Nanga Dangkan 1 Kecamatan Silat Hulu.

Pada organisasi Komite Sekolah di Sekolah Dasar Negeri 01 Desa Nanga Dangkan 1 sudah dilakukan delegasi wewenang antar pengurus. Cara delegasi wewenang tersebut adalah dari Ketua Komite kepada Wakil Ketua, Sekretaris Komite dan Bendahara Komite. Dan, dari Ketua Komite Sekolah kepada Seksi yang menangani setiap bidang. Menurut Kepala Sekolah Dasar Negeri 01 Desa Nanga Dangkan 1 aspek-aspek yang diperhatikan dalam delegasi wewenang adalah harus sesuai dengan tugas, pokok dan fungsi dari masing-masing pengurus Komite Sekolah. Delegasi wewenang tersebut dapat meningkatkan pelaksanaan uraian tugas pengurus Komite Sekolah. Kewenangan pengambilan keputusan yang tersebar secara luas dan hirarki organisasi disebut dengan desentralisasi. Sedangkan apabila kewenangan dalam proses pengambilan keputusan hanya berada pada tingkat atas dalam organisasi disebut sentralisasi. Keberadaan Komite Sekolah di setiap satuan pendidikan atau kelompok satuan pendidikan adalah untuk meningkatkan mutu pendidikan di satuan pendidikan tersebut. Ada prinsip yang harus dipegang oleh semua pengurus Komite Sekolah yaitu Komite Sekolah tidak mengambil peran satuan pendidikan, tidak juga mengambil peran pemerintah atau birokrat. Delegasi wewenang tersebut dapat meningkatkan pelaksanaan uraian tugas pengurus Komite Sekolah.
Mekanisme koordinasi dalam pelaksanaan tugas dan fungsi Komite Sekolah dilakukan melalui surat tugas. Metode yang diterapkan dalam pelaksanaan mekanisme koordinasi tugas pengurus Komite dengan perangkat Sekolah Dasar Negeri 01 adalah dengan pembagian tugas dan perintah dari Ketua Komite Sekolah dan Kepala Sekolah sebagai mitra kerja. Peran komite sekolah adalah sebagai mediator antara sekolah dan masyarakat yang dianggap sebagai kriteria kefektifan komite. Banyak yang menganggap bahwa dengan lingkungan kerja yang bagus dan anggota yang berkualitas sangat penting, sehingga komite dapat bekerja secara efektif bersama-sama dengan sekolah dan masyarakat untuk meningkatkan mutu belajar mengajar. Jadwal pertemuan antara pihak sekolah dengan pengurus Komite Sekolah hanya ada 2 kali dalam setahun, yaitu tahun ajaran baru, mau menghadapi ujian akhir dan rapat yang tidak terjadwal ini dengan melihat dasar keperluan sekolah khususnya dalam perencanaan penyusunan program sekolah.

Penyusunan desain pekerjaan pada pengurus Komite Sekolah belum terlaksana dengan baik. Selanjutnya, karena belum adanya penyusunan maka belum diketahui apakah desain pekerjaan tersebut dilakukan dengan penyederhaan tugas atau pemekaran pekerjaan. Desain pekerjaan berpengaruh besar terhadap efektifitas organisasi. Pekerjaan yang dirancang dengan baik akan dapat meningkatkan motivasi yang merupakan salah satu faktor yang menentukan kinerja pengurus Komite Sekolah. Kepuasan kerja dipengaruhi oleh tuntutan pekerjaaan dan oleh sejauh mana tuntutan tugas tersebut sesuai dengan kemampuan seseorang.Kadangkala perubahan tugas yang sangat simpel dapat menyebabkan perubahan besar pada pemegang tugas tersebut.

Komite Sekolah merupakan asas utama dalam suatu organisasi yang menjadi perencana dan pelaku aktif dari setiap aktifitas organisasi, setiap orang akan berupaya menbangun, mendayagunakan semua sumber organisasinya secara optimal dalam rangka mencapai tujuannya. Sebagai salah satu sumber daya organisasi yang sangat penting, maka pengurus Komite Sekolah perlu diperhatikan/dirancang sedemikian rupa agar dapat memenuhi harapan sebuah organisasi. Sehingga mempengaruhi administrasi dapat berjalan dengan baik, yakni sesuai dengan harapan maka perlu didukung oleh kualitas pengurus Komite Sekolah yang memadai. Sistem penempatan pengurus Komite Sekolah di Sekolah Dasar Negeri 01 Desa Nanga Dangkan 1 Kecamatan Silat Hulu berdasarkan dari tingkat pendidikan dan pengalaman selama menjadi pengurus Komite Sekolah sebelumnya. 
Jumlah pengurus Komite Sekolah di Sekolah Dasar Negeri 01 Desa Nanga Dangkan 1 Kecamatan Silat Hulu sudah memadai. Dalam penempatan organisasi Komite Sekolah pada Sekolah Dasar Negeri 01 Desa Nanga Dangkan 1 Kecamatan Silat Hulu diketemukan adanya kendala hal ini disebabkan karena adanya : kendala biaya yang mana seharusnya biaya dari orang tua murid, tenaga yang masih kurang, baik dari kemampuan maupun tenaga yang bersifat sosial, serta belum adanya panduan khusus tentang sistem dan cara kerja dari Komite Sekolah. Solusi untuk mengatasi kendala tersebut adalah dengan berkoordinasi dengan pihak perangkat Sekolah untuk lebih mengoptimalkan kinerja Komite Sekolah karena selama ini yang terjadi Komite Sekolah dibentuk hanya untuk formalitas saja. Dan, juga Ketua Komite dan pengurus Komite harus segera membuat panduan khusus tentang sistem kerja dan cara kerja Komite Sekolah.

Kemampuan, kecakapan, dan keterampilan pengurus Komite Sekolah tidak ada artinya bagi organisasi apabila pengurus Komite Sekolah tidak atau kurang berkemauan untuk melakukan pekerjaan yang telah di percayakan kepadanya. Oleh karena itu faktor yang sangat menentukan adalah dorongan yang ada pada diri manusia yakni motivasi itu sendiri. Hal inilah yang menjadi tanggung jawab Ketua Komite Sekolah untuk mengarahkan dan mendorong para pengurus Komite Sekolah untuk bekerja lebih baik sesuai dengan kemauan dan arahan pimpinan. Dalam hal ini bahwa belum adanya motivasi Komite Sekolah dalam pelaksanaan tugas dan fungsi khususnya dalam perencanaan penyusunan program sekolah di Sekolah Dasar Negeri 01 Desa Nanga Dangkan 1 Kecamatan Silat Hulu. Teknik motivasi yang diberikan adalah motivasi tidak langsung, yaitu motivasi yang diberikan hanya merupakan fasilitasfasilitas yang mendukung serta menunjang gairah kerja atau kelancaran tugas, sehingga pengurus Komite Sekolah betah dan bersemangat melakukan tugas dan fungsinya.

\section{KESIMPULAN DAN SARAN}

Pelaksanaan tugas dan fungsi Komite Sekolah dalam perencanaan penyusunan program sekolah pada Sekolah Dasar Negeri 01 Desa Nanga Dangkan 1 Kecamatan Silat Hulu menunjukkan bahwa pada pembagian tugas sudah dilakukan antar pengurus Komite Sekolah, tetapi masih belum dilaksakan dengan baik sesuai dengan tugas dan fungsi dari masing-masing pengurus. Delegasi wewenang sudah ada, dan mekanisme koordinasi masih belum dijalankan dengan baik. Untuk desain pekerjaan, karena pembagian tugas sudah ada, tetapi desain pekerjaan yang dijalankan belum terlaksana dengan baik. Faktor-faktor yang mempengaruhi pelaksanaan tugas dan fungsi pada Komite Sekolah Dasar Negeri 01 Desa Nanga Dangkan 1 Kecamatan Silat Hulu, pada manajemen sumber daya manusianya masih perlu diadakan pembinaan kepada pengurusnya sementara tingkat motivasi yang ada masih kurang dimiliki oleh pengurus Komite Sekolah. Upaya yang dilakukan pimpinan dalam meningkatkan motivasi pengurus Komite Sekolah dalam pelaksanaan tugas dan fungsi adalah dengan cara memberikan insentif setiap bulannya dan honor-honor atas pelaksanaan kegiatan / program yang dilakukan setiap bulannya.

Pelaksanaan tugas dan fungsi Komite Sekolah dapat berjalan dengan baik maka memang perlu adanya pertemuan untuk merumuskan panduan mengenai sistem dan cara kerja dari Komite Sekolah. Untuk mengantisipasi kurangnya manajemen sumber daya manusia,dan motivasi maka dapat memberikan insentif setiap bulannya dan honor-honor atas pelaksanaan kegiatan/ program yang dilakukan setiap bulannya serta penghargaan kepada pengurus Komite Sekolah yang melaksanakan tugas dan fungsinya dengan penuh tanggung jawab.

\section{DAFTAR PUSTAKA}

Arikunto, S, 2000. Prosedur Penelitian, Suatu Pendekatan Praktek. Jakarta: PT. Rineka Cipta

Bagong, S \& Sutinah. 2007. Metode Penelitian Sosial: Berbagai Alternatif Pendekatan. Jakarta: Prenada Media Grup

Cullen, Barry. 2004. Human Resources Management, Perencanaan, Analisis, Kinerja dan Penghargaan. Jakarta: PT. Elex Media Komputindo

Dessler, Gary. 1985. Management Fundamentals. Edisi Keempat. Virginia: Reston Publishing Company

Gitosudarmo, dan Sudita. 2000. Perilaku Organisasi. Yogyakarta: BPFE.

Hasibuan, S.P. 1996. Manajemen : Dasar, Pengertian dan Masalah, Jakarta: PT. Bumi Aksara.

Husnan, HS. 1997. Manajemen Personalia. Yogyakarta: BPFE

Kumorotomo, W. 1994. Etika Administrasi Negara. Yogyakarta: PT. Tiara Wacana.

Lembaga Administrasi Negara RI. 1999. Administrasi Perkantoran. Jakarta: LAN 
Nawawi, H, 2001. Metode Penelitian Bidang Sosial. Yogyakarta: Gadjah Mada Press

Sedarmayanti, Dr, Prof. 2007. Manajemen Sumber Daya Manusia, Reformasi Birokrasi dan Manajemen Pegawai Negeri Sipil. Bandung: PT. Refika Aditama.

Siagian, Sondang P. 1996. Manajemen Sumber Daya Manusia. Jakarta: Bumi Aksara.

Strategik. Jakarta: .Bumi Aksara.

2000. Manajemen

Sugiyono. 2007. Metode Penelitian Kuantitatif, Kualitatif dan $R \& D$. Jakarta: CV. Alfabeta.
Peraturan Perundangan :

SK Menteri Pendidikan Nomor 202 Tahun 2003. Tentang Komite Sekolah. Jakarta: Departemen Pendidikan.

Undang-Undang Nomor 25 Tahun 2000. Tentang Program Pembangunan Nasional (PROPENAS). Jakarta : UU.

Undang-Undang Otonomi Daerah Nomor 32 Tahun 2004. Tentang Pemerintahan Daerah. Bandung: Citra Umbara

Undang-Undang Pendidikan Tahun 2003. Tentang Desentralisasi Pendidikan. Jakarta: UU. 